\title{
Prevalence of oral cancer self-examination among elderly people treated under Brazil's Unified Health System: household health survey
}

\author{
Andréa Maria Eleutério de Barros Lima Martins ${ }^{1}$ \\ João Gabriel Silva Souza ${ }^{2}$ \\ Desireé Sant'Ana Haikal ${ }^{1}$ \\ Alfredo Maurício Batista de Paula ${ }^{1}$ \\ Efigênia Ferreira e Ferreira ${ }^{3}$ \\ Isabela Almeida Pordeus ${ }^{4}$
}

${ }^{1}$ Departamento de Odontologia, Centro de Ciências Básicas e da Saúde, Universidade Estadual de Montes Claros. Av. Dr. Rui Braga s/n, Vila Mauricéia. 39401-089 Montes Claros MG Brasil. martins. andreamebl@gmail.com ${ }^{2}$ Departamento de Ciências Fisiológicas, Universidade Estadual de Campinas.

${ }^{3}$ Departamento de Odontologia Social e Preventiva, Universidade Federal de Minas Gerais.

${ }^{4}$ Departamento de

Odontopediatria,

Universidade Federal de Minas Gerais.
Abstract The aim of this study was to examine the prevalence of oral cancer self-examinationamong the elderly and confirm whether prevalence was higher among users of the dental services provided by Brazil's Unified Health System (SUS, acronym in Portuguese). A transversal study of elderly people aged between 65 and 74 years living in a large-sized Brazilian municipality was conducted using simple random sampling. Logistic regression was conducted and results were corrected for sample design and unequal weighting using the SPSS ${ }^{\circledR}$ software. The study assessed 740 individuals. A total of 492 met the inclusion criteria, of which 101 (22.4\%) reported having performed an oral cancer self-examination. Prevalence was higher among users of the dental services provided by the SUS, higher-income individuals, people with higher levels of education, individuals that used a removable dental prosthesis, and people who had not experienced discomfort attributed to oral condition, and lower among people who sought regular and periodic dental treatment and individuals who did not have a drinking habit. This type of self-care should be encouraged by public health policies which respond to the needs of the elderly, with emphasis on users of private and philanthropic services, and other services outside the public health network.

Key words Oral neoplasia, Elderly, Unified Health System, Self-examination, Health literacy 


\section{Introduction}

Social inequality is widespread in Brazil. The history of public health in Brazil is marked by the creation of the Unified Health System (SUS, acronym in Portuguese) in 1988, whose underlying principles include equity, universality and comprehensiveness. Since the creation of the SUS, significant investments have been made in human resources, science and technology, and Primary Health Care (PHC), and a significant portion of the Brazilian population has been able to access healthcare services. The health care system in Brazil has also become increasingly decentralised and social participation and awareness among the population regarding the right to healthcare has broadened. However, certain challenges remain to be overcome by the SUS, including the provision of equitable and sustainable universal coverage, and the transition towards a healthcare model which is capable of addressingdemographic and epidemiological changes, centred on promoting health through intersectoral action and the integration of health services. These challenges are not technical, but rather political, and can only be solved through the joint efforts of individuals and society. To overcome these challenges, greater political mobilisation is necessary to restructure funding and redefine the roles of the public and private health sectors so as to ensure the political, economic, scientific and technological sustainability of the SUS ${ }^{1}$. Given the importance of the social dimension of the SUS in Brazil, there is a need to learn from past successes and failures in order to confront the challenges highlighted above and consolidate the system's principles ${ }^{2}$. A number of improvements have been observed in public health policies, especially those which respond to the needs of priority groups such as the elderly ${ }^{3}$, who comprise a growing segment of Brazilian society ${ }^{4}$. In 2004, oral health was incorporated into the SUS through the creation of the National Oral Health Policy, which addresses oral health care among the elderly ${ }^{5}$.

The rise in the elderly population around the world is a result of socioeconomic transformation and changes in habits. This segment of the population is more exposed to risk factors for cancer and other chronic degenerative diseases. In Brazil, cancer, considered a worldwide public health problem, is one of the leading causes of death ${ }^{6}$. In 2012, there were 14.1 million new cases of cancer around the world and a total of 8.2 milliondeaths due to the disease. Without pre- ventative measures, the cancer burden is likely torise in developing countries and is expected to grow at an even faster pace in developed countries. The number of new cases of oral cancer among males in Brazil was estimated at 11,280 in 2014, which is equivalent to an estimated risk of 11.5 new cases per 100,000 men, while in women the number of cases and estimated risk were 4,010 and 3.92 per 100,000, respectively. Excluding nonmelanoma skin cancer, oral cancer is the fifth most common cancer among men and the eleventh most common among women ${ }^{7}$. The distribution of new cases of this type of cancer in Brazil is heterogeneous, with the greatest concentration of cases in the Southeast and South regions of the country ${ }^{8}$. Tobacco and alcohol are the main risk factors for the disease, principally when their use is combined ${ }^{9,10}$. Social determinants, such as precarious socioeconomic situation and poor education, are also risk factors ${ }^{11}$.

The early diagnosis of oral cancer may occur in the following circumstances: 1) the detection of suspicious skin lesions during a visit to the dentist; 2) Screening followed by dental examination as a result of the detection of suspicious skin lesions; 3 ) dental examination as a result of oral cancer self-examination where the patient detected something unusual. In the above cases, after oral examination performed by an oral health professional, it is necessary to carry out a histopathological examination to confirm the suspicion. Screening is only carried out in some localities and is often only available on a periodic basis. If people are advised to carry out oral self -examination, including during periods between dental consultations, for various reasons and/or screenings, this would ensure the greatest possibility of early diagnosis and treatment of this cancer, including in locations where screening is not a standard policy, where the policy has not yet been established, and also in locations where the policy is already standard.

A randomized clinical trial conducted in Kerala in India over a period of nine years (1996 to 2004) implemented educational activities and screening by trained professionals to detect cancerous lesions, followed by early diagnosis and immediate treatment of oral cancer, among a sample of 167,741 individuals, while a control group received normal health service. The rate of mortality due to oral cancer among male smokers and drinkers, and fatalities among individuals with oral cancer were lower in the test group than in the control group ${ }^{12}$. Access to information on how to prevent oral cancer through oral cancer 
self-examination followed by an examination carried out by an oral health professional facilitates early diagnosis. Health education therefore plays an important role in health promotion and the prevention of oral cancer. In light of this, health promotion and oral cancer prevention policies have been implemented in a number of localities in Brazil ${ }^{13,14}$.

Oral cancer self-examination is a non-invasive, reliable and low cost method of early detection of suspicious oral lesions recommended for the general population ${ }^{15}$ and is also an effective way of increasing awareness of oral cancer ${ }^{16}$. Oral cancer self-examinationis an integral part of public health policies directed towards the prevention and early diagnosisof oral cancer ${ }^{15}$. Therefore, the identification of the factors which influence (or are influenced by) oral cancer self -examination can help elucidate and expand this practice, especially among the elderly. Within the context of the SUS, PHC settings are particularly appropriate environments for health promotion activities, such as control of risk factors, early diagnosis of oral cancer and health care ${ }^{14}$. Dental services provided under Brazil's PHC system include actions in the community based on health promotion, disease prevention and health education $^{13}$. Health education may remove the barriers to early diagnosis, and reduce the time elapsed between the detection of signs of cancer through self-examination and treatment ${ }^{14}$. With regard to health promotion, the objective of health education is to improve "health literacy". In 2012, Sørensen et al., presented a theoretical model containing variables which influence and are influenced by the level of health literacy ${ }^{17}$ (Figure1).

The mode ${ }^{17}$ shows proximal and distal factors which determine and/or are determined byhealth literacydesignated by the following characteristics: previous knowledge of the relevant health topic, competences and motivation to access (capacity to seek, find and obtain health information), understand (capacity to understand the relevant health information), assess (capacity to interpret, filter and judge the information received) and apply (capacity to communicate and use the information to take decisions which maintain or improve one's health status) health-related information. The model presents a number of factors related to health literacy: distal causes include the main determining factors or consequences attributed to social and environmental conditions (demographic situation, culture, language, political forces and social systems), while proximal causes include those rela- ted to social situation (support, family and peer influence, use of the media and state of the physical environment), and those regarding personal determinants (age, sex, race, socioeconomic status, education, occupation, employment, income and level of schooling). The authors also suggest other factors which may be related to health literacy (determinants and/or consequences): use of health services, health costs, health behaviours, health outcomes, participation, empowerment, equity and maintenance. The model shows that there is a feedback relationship between all factors and health literacy ${ }^{17}$, with the exception of age and race, which remain the same regardless of health literacy. Empowerment, which may be related to a high level of health literacy ${ }^{17}$, refers to social action that promotes the participation of people, organisations and communities in their own destiny or that of society as a whole ${ }^{18}$.

Oral cancer self-examination may be one of the consequences of empowerment and health education in people with a high level of "health literacy". Thus, the analysis of the prevalence of self-examination and differences in levels of prevalence among users of the dental services provided by the SUS and users of other services outside the public health system may provide a valuable input to public health policies. Given the lack of research on this issue, this study therefore proposes an assessment of oral cancer self-examination based on the theoretical model created by Sørensen et al. ${ }^{17}$.

\section{Methodology}

A transversal analytic study was conducted between2008 and 2009 using a random sample of individuals aged between 65 and 74 years living in Montes Claros, a large-sized municipality in the state of Minas Gerais, Brazil ${ }^{19}$. Sample size was calculated based upon an estimate of the proportion of occurrences of events or diseases in $50 \%$ of the population, a standard error of $5.5 \%$, a $20 \%$ non-response rate, proportionality between gender, and a design effect of 2.0. Clusters were selected using simple random sampling. The estimated minimum sample size was 740 based on a total elderly population of 9,929 .

The study assessed individuals who said that they had used dental services and had answered the question about oral cancer self-examination. Individuals with cognitive problems were excluded from the study. The participants were assessed using the mini Brazilian version of the men- 


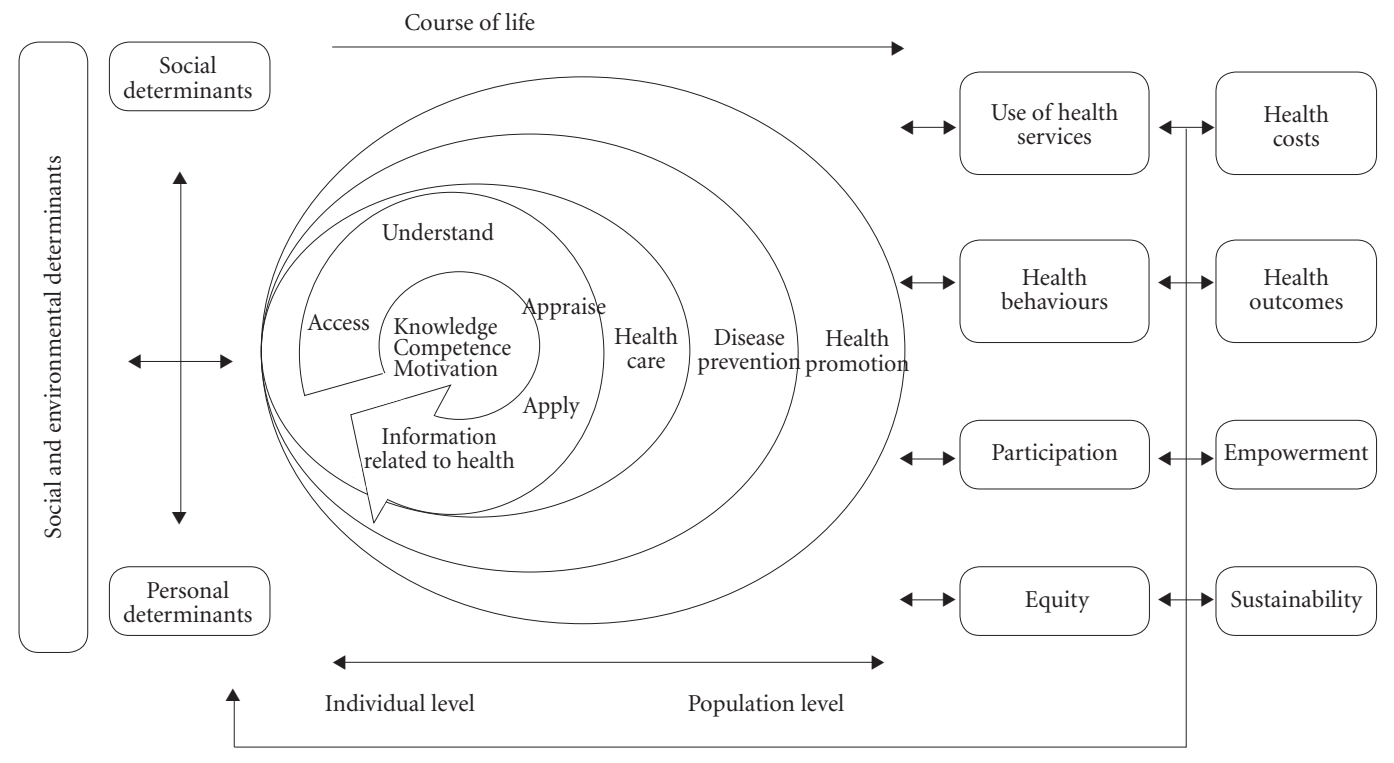

Figure 1. Theoretical model of health literacy presented by Sørensen et al. (2012).

Source: Sørensen et al., $2012^{17}$.

tal state examination $(\mathrm{MMSE})^{20}$. The following cut-points were established for level of education: 21 (illiterate), 22 (low level of education one to five years of schooling), 23 (medium level of education - six to 11 years of schooling), and 24 (high level of education - 12 or more years of schooling $)^{21}$. Those individuals whose MMSE score was under that of the relevant cut-point were defined as having cognitive impairment and were excluded from the study. The assessment of oral health status was carried out in accordance with World Health Organization (WHO, 1997) diagnostic criteria ${ }^{22}$. Data collection was carried out by trained dentists assisted by dental students in a spacious environment under natural light and using a sterilised mirror and periodontal probe. Data was calibrated using Kappa statistics and the intraclass correlation coefficient $(\alpha=$ 0.61 for inter and intraexaminer reliability) and stored in notebook developed for this study ${ }^{19}$.

The dependent variable was based on the following question: "have you ever performed self-examination of your mouth? (yes/no)". Based on the model developed by Sørensen et al., independent variables were combined into the following five groups each with respectivesubcategories: personal determinants, health services/ health costs, health behaviours, and health outcomes $^{17}$. The personal characteristics subcategories were age, self-declared race, sex, marital status, years of schooling, income measured in number of minimum salaries. The health services/health costs subcategories were type of dental service used (SUS/private/philanthropic/other services outside the public health network), and the main independent variable was time, in years, since the last visit to the dentist and motive for the visit.

The health behaviours subcategories were current and past smoking habits, and current and past drinking habits. Health outcomes subcategories were presence of chronic diseases based on the general health statusreported by the participant. Objectiveand subjective oral health status was assessed. Objective status included alterations in oral soft tissueand use of removable dentures, while subjective oral health status was based on self-perception (need for dental treatment, toothache and painful gums in the previous six months, uncomfortable feeling in the mouth, head or neck), and on an assessment of 
impacts due to oral disorders using the Brazilian version of the Oral Health Impact Profile (OHIP14). This questionnaire is made up of 14 questions which measure discomfort attributed to oral condition in the last 12 months ${ }^{23}$. Questions are answered based on a five-point Likert scale with the following response categories: "Always", "Fairly often", "Occasionally", "Hardly Ever" and "Never". Those individuals who answer "Always" or "Fairly often" to at least one of the 14 questions are considered to have suffered an impact attributed to oral disorders ${ }^{24}$.

Data was analysed using the SPSS ${ }^{\circledR}$ Statistics 18.0 software. Given that the study involved a complex form of cluster sampling, data was corrected for sample designand unequal weighting. The descriptive analysis of the categorical variables used corrected relative frequency (\%), standard error (SE) and design effect (Deff). With respect to the quantitative variables, the mean, SE and Deff were calculated and corrected for the design effect. The results of the bivariate analysis and logistic regression, conducted to identify factors associated with the dependent variable, were corrected for design effect. The odds ratio, 95\% confidence intervals (OR/IC 95\%), p-value and Deff were calculated. A significance level of $20 \%$ ( $\alpha=0,20)$ was adopted for the bivariate analysis to select the independent variables, and 5\% $(\alpha=0,05)$ for the multivariate analysis/logistic regression. The final multivariate model was adjusted to retain only those independent variables associated with the dependent variable. The study was carried out in accordance with the ethical principles contained in the National Health Council Resolution Nº196/9625.

\section{Results}

The study assessed 740 individuals (92\% response rate). A total of 492 met the inclusion criteria, of which 101 (22.4\%) reported having performed an oral cancer self-examination. The average age of the sample was 68.35 years (SE 0.16, Deff 1.47). The majority of the sample was female, had zero to four years of schooling, used private dental services, or received treatment outside the public health network, and did not present changes in the oral mucosa (Table 1).

Bivariate analysis to select the independent variables showed a significant association (20\%) between oral cancer self-examination and selfdeclared race, education level, per capita income, type of dental service used, motive of use, drinking habits, use of a removable denture and self-perception of toothache and painful gums in the previous six months (Table 2).

Multiple logistic regression showed an association between oral cancer self-examination and personal determinants, health services/health costs, health behaviours, and health outcomes (Table 3).

\section{Discussion}

The low prevalence of oral cancer self-examination found among the elderly in Montes Claros $(22.4 \%)$ is of concern, since the elderly are more susceptible to oral cancer than other segments of the population ${ }^{26}$. Prevalence was higher among individuals treated under the SUS (31\%). A previous study observed an oral cancer self-examination prevalence rate of $7.2 \%$ among a sample with an average age of 52.7 years ${ }^{27}$. In contrast, another study observed a prevalence rate of $68.9 \%$ among young adults ${ }^{28}$. These differences may be explained by the age of the individuals assessed by these studies, which is called the "cut-off effect". Other reasons may include differences in the sociodemographic characteristics of the samples. The lower prevalence of oral cancer self-examination among older people compared to young adults is to be expected due to low health literacy which engenders vulnerability to cancer ${ }^{29}$. This vulnerability was observed by a quantitative-qualitative study with a sample of older people which examined the role of health literacy practices. The study collected information about reading and writing habits and related difficulties, and the relevance of these habits among older people, and showed that the elderly acknowledge that these activities contribute to promoting healthy and active ageing and improvements in cognition. However, the participants of this study highlighted a number of difficulties including those related to spelling, texts, and biological terms ${ }^{29}$. Furthermore, low levels of income and/or education may also accentuate vulnerability related to the level of health literacy attributed to educational activities that envisage health promotion. Educational activities can also have an influence on the self-perception of oral health status, help patients detect oral problems and promote self-care to prevent or treat oral diseases in their early stages ${ }^{30}$. The self-perception of oral health among the majority of Brazilian elderly is satisfactory, even when it is actually poor ${ }^{31}$. It is possible that many older people feel that self-exa- 
Table 1. Descriptive analysis of the prevalence of oral cancer self-examination, personal characteristics, use of health services, health costs, health behaviours, and health outcomes among the elderly in Montes Claros/Minas Gerais, 2008/2009. $\mathrm{n}=492$.

\begin{tabular}{|c|c|c|c|}
\hline Variables & $\%^{\mathrm{a}}$ & SE & Deff \\
\hline \multicolumn{4}{|l|}{ Oral cancer self-examination } \\
\hline No & 77,6 & & \\
\hline Yes & 22,4 & 2,9 & 2,604 \\
\hline \multicolumn{4}{|l|}{ Personal characteristics } \\
\hline \multicolumn{4}{|l|}{ Age (years) } \\
\hline 69 to 74 & 41,5 & & \\
\hline 65 to 68 & 58,5 & 2,6 & 1,495 \\
\hline \multicolumn{4}{|l|}{ Self-declared race ${ }^{\mathrm{b}}$} \\
\hline Brown & 45,4 & 3,7 & 2,949 \\
\hline Black & 16,1 & 2,2 & 1,903 \\
\hline Indigenous & 0,5 & 0,4 & 1,653 \\
\hline Yellow & 0,9 & 0,5 & 1,319 \\
\hline White & 37,1 & 4,7 & 5,133 \\
\hline \multicolumn{4}{|l|}{ Sex } \\
\hline Male & 47,8 & & \\
\hline Female & 52,2 & 2,7 & 1,645 \\
\hline \multicolumn{4}{|l|}{ Marital status } \\
\hline Single/Widower/Divorced & 30,8 & & \\
\hline Married/Stable union & 69,2 & 3,4 & 2,972 \\
\hline \multicolumn{4}{|l|}{ Schooling (years of study) } \\
\hline 0 to 4 years & 59,1 & & \\
\hline 5 years or over & 40,9 & 5,2 & 3,958 \\
\hline \multicolumn{4}{|c|}{ Income measured in number of minimum salaries ${ }^{\mathrm{b}, \mathrm{c}}$} \\
\hline One or less & 66,8 & & \\
\hline More than one & 33,2 & 4,0 & 3,842 \\
\hline \multicolumn{4}{|l|}{ Health services/health costs } \\
\hline \multicolumn{4}{|l|}{ Type of dental service used ${ }^{\mathrm{b}}$} \\
\hline Public/SUS & 27,5 & 4,4 & 5,282 \\
\hline Private & 62,4 & 3,6 & 2,956 \\
\hline Other services outside the public network & 9,7 & 2,0 & 2,475 \\
\hline Philanthropic & 0,4 & 0,2 & 0,734 \\
\hline \multicolumn{4}{|l|}{ Household registered in the ESF } \\
\hline No & 43,6 & & \\
\hline Yes & 56,4 & 8,4 & 15,885 \\
\hline \multicolumn{4}{|l|}{ Time elapsed since last visit to the dentist (years) } \\
\hline One or more & 72,9 & & \\
\hline Less than one & 27,1 & 2,8 & 2,112 \\
\hline \multicolumn{4}{|l|}{ Reason for using dental service } \\
\hline Treatment & 62,9 & & \\
\hline Routine & 37,1 & 3,6 & 2,994 \\
\hline
\end{tabular}

continua

mination is unnecessary due this false perception of good oral health status. The low prevalence of oral cancer self-examinationamong the present study sample may be related to the lack of knowledge about the need for self-examination and self-care or the lack of access to information on how to perform self-examination. Research carried out in the United States showed that, despite the fact that the majority of dentists agree thatoral cancer self-examinationis important for prevention purposes, less than half provide their patients with information on the subject ${ }^{32}$. It should be noted that this question has not been investigated in Montes Claros. The likelihood of an oral examination performed by a dentist is greater when an individual practices oral cancer self-examination because the individual is more likely to perceive the need to seek professional 


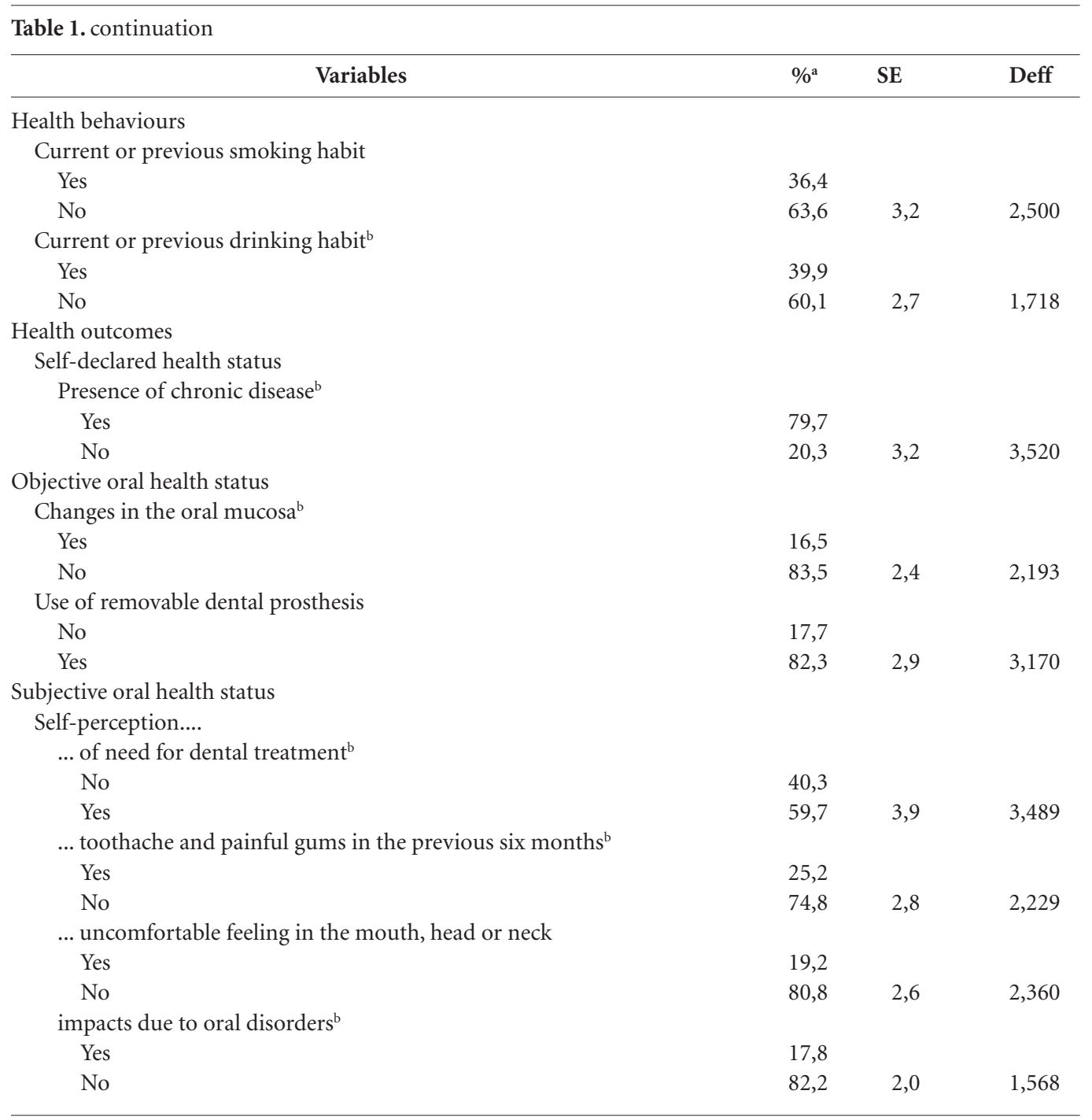

${ }^{\mathrm{a}}$ Estimated values corrected for design effect. ${ }^{\mathrm{b}}$ Variation $\mathrm{n}=492$ due to loss of information. ${ }^{\mathrm{c}}$ Based on minimum salary in 2008 ( R\$ 415).

care. As a result, oral cancer self-examination is likely to lead to an increase in the prevalence of the early diagnosis of oral cancer resulting in the need for less invasive treatments.

Apart from the low prevalence of oral cancer self-examination, the results of this study showed an association between performing oral cancer self-examination and certain variables in the subcategories personal determinants, health services/health costs, health behaviours, and health outcomes. Studies which examine the factors associated with performing oral cancer self-examination among the elderly were not found. The results of the present study in Monte Claros show that the likelihood of oral cancer self-examina- tionis greater in higher-income individuals and those with higher levels of education, showing the effects of social inequality on vulnerability. Higher socioeconomic status probably contributes towards a higher level of health literacy and therefore a reduction in vulnerability. Social inequalities in oral health in Brazil ${ }^{33}$ show the ineffectiveness of the system with respect to the fulfilment of the equity principle set by the SUS. However, it is important to highlight that higher levels of education and income reflect improvements in socioeconomic conditions, which in turn may lead to greater awareness with regard to health status and the wider adoption of preventive health behaviours. Although advances have 
Table 2. Bivariate analysis of oral cancer self-examination and personal characteristics, use of health services/ health costs, health behaviours, and health outcomes among the elderly in Montes Claros/Minas Gerais, 2008/2009. $\mathrm{n}=492$

\begin{tabular}{|c|c|c|c|c|c|c|}
\hline \multirow[b]{2}{*}{ Variables } & \multicolumn{2}{|c|}{ Oral self-examination } & \multirow[b]{2}{*}{$\mathrm{OR}^{\mathrm{a}}$} & \multirow[b]{2}{*}{ IC $95 \%{ }^{a}$} & \multirow[b]{2}{*}{$\mathbf{P}$} & \multirow[b]{2}{*}{ Deff } \\
\hline & $\begin{array}{l}\text { No } \\
\%^{a}\end{array}$ & $\begin{array}{l}\text { Yes } \\
\%^{a}\end{array}$ & & & & \\
\hline \multicolumn{7}{|l|}{ Personal characteristics } \\
\hline \multicolumn{7}{|l|}{ Age (in years) } \\
\hline 69 to 74 & 77,8 & 22,2 & 1,00 & & & \\
\hline 65 to 68 & 77,5 & 22,5 & 1,01 & $0,65-1,55$ & 0,954 & 1,05 \\
\hline \multicolumn{7}{|l|}{ Self-declared race ${ }^{\mathrm{b}}$} \\
\hline Brown/Black/Indigenous & 74,5 & 25,5 & 1,00 & & & \\
\hline White/Yellow & 82,7 & 17,3 & 0,61 & $0,35-1,04$ & 0,066 & 1,44 \\
\hline \multicolumn{7}{|l|}{ Sex } \\
\hline Male & 75,4 & 24,6 & 1,00 & & & \\
\hline Female & 79,6 & 20,4 & 0,78 & $0,43-1,41$ & 0,410 & 2,02 \\
\hline \multicolumn{7}{|l|}{ Marital status } \\
\hline Single/Widower/Divorced & 78,6 & 21,4 & 1,00 & & & \\
\hline Married/Stable union & 77,2 & 22,8 & 1,08 & $0,65-1,78$ & 0,752 & 1,23 \\
\hline \multicolumn{7}{|l|}{ Schooling (years of study) } \\
\hline 0 to 4 years & 81,4 & 18,6 & 1,00 & & & \\
\hline 5 years or over & 72,2 & 27,8 & 1,69 & $0,94-3,04$ & 0,070 & 1,98 \\
\hline \multicolumn{7}{|l|}{$\begin{array}{l}\text { Income measured in number } \\
\text { of minimum salaries }{ }^{\mathrm{b}, \mathrm{c}}\end{array}$} \\
\hline One or less & 80,3 & 19,7 & 1,00 & & & \\
\hline More than one & 72,2 & 27,8 & 1,57 & $1,00-2,46$ & 0,041 & 1,07 \\
\hline \multicolumn{7}{|l|}{ Health services/health costs } \\
\hline \multicolumn{7}{|l|}{ Type of dental service used ${ }^{b}$} \\
\hline $\begin{array}{l}\text { Other services outside the public network/ } \\
\text { Private/Philanthropic }\end{array}$ & 80,8 & 19,2 & 1,00 & & & \\
\hline SUS & 69,0 & 31,0 & 1,88 & $0,80-4,41$ & 0,138 & 1,88 \\
\hline \multicolumn{7}{|l|}{ Household registered in the ESF } \\
\hline No & 80,6 & 19,4 & 1,00 & & & \\
\hline Yes & 75,3 & 24,7 & 1,36 & $0,76-2,44$ & 0,283 & 1,88 \\
\hline \multicolumn{7}{|c|}{ Time elapsed since last visit to the dentist (years) } \\
\hline One or more & 78,9 & 21,1 & 1,00 & & & \\
\hline Less than one & 74,2 & 25,8 & 1,29 & $0,80-2,09$ & 0,269 & 1,11 \\
\hline \multicolumn{7}{|l|}{ Reason for using dental service ${ }^{b}$} \\
\hline Treatment & 74,5 & 25,5 & 1,00 & & & \\
\hline Routine & 82,7 & 17,3 & 0,61 & $0,32-1,16$ & 0,121 & 2,03 \\
\hline
\end{tabular}

been made through the creation and implementation of public policies in recent years, such as the inclusion of an oral health team in the Family Health Strategy (ESF, acronym in Portuguese), efforts are necessary to put a comprehensive policy into effect which is capable of reducing inequality in access to dental services and the oral health care process ${ }^{34}$.

A major finding of this study is that the prevalence of oral cancer self-examination was greater in individuals that used the SUS, suggesting that relevant policies ${ }^{3,4}$ are generating a positive impact. This seems to be a paradox, given that prevalence of oral cancer self-examination was greater in higher-income individuals and those with higher levels of education. However, it is possible that health professionals working in the SUS provide more information regarding the importance of oral cancer self-examination than those working in other settings, in an attempt to reduce health inequalities. The greater prevalence of oral cancer self-examination in individuals that used the SUS may therefore be explained by the greater emphasis given to health promotion 
Table 2. continuation

\begin{tabular}{|c|c|c|c|c|c|c|}
\hline \multirow{3}{*}{ Variables } & \multicolumn{2}{|c|}{ Oral self-examination } & \multirow[b]{3}{*}{$\mathrm{OR}^{\mathrm{a}}$} & \multirow[b]{3}{*}{ IC $95 \%{ }^{a}$} & \multirow[b]{3}{*}{$\mathbf{P}$} & \multirow[b]{3}{*}{ Deff } \\
\hline & No & Yes & & & & \\
\hline & $\%^{a}$ & $\%^{a}$ & & & & \\
\hline \multicolumn{7}{|l|}{ Health behaviours } \\
\hline \multicolumn{7}{|c|}{ Current or previous smoking habit } \\
\hline Yes & 76,0 & 24,0 & 1,00 & & & \\
\hline No & 78,6 & 21,4 & 0,86 & $0,51-1,43$ & 0,556 & 1,43 \\
\hline \multicolumn{7}{|c|}{ Current or previous drinking habit ${ }^{\mathrm{b}}$} \\
\hline Yes & 73,2 & 26,8 & 1,00 & & & \\
\hline No & 80,6 & 19,4 & 0,65 & $0,39-1,08$ & 0,092 & 1,46 \\
\hline \multicolumn{7}{|l|}{ Health outcomes } \\
\hline \multicolumn{7}{|l|}{ Self-declared health status } \\
\hline \multicolumn{7}{|l|}{ Presence of chronic disease $\mathrm{b}^{\mathrm{b}}$} \\
\hline Yes & 78,3 & 21,7 & 1,00 & & & \\
\hline No & 74,9 & 25,1 & 1,21 & $0,69-2,12$ & 0,490 & 1,26 \\
\hline \multicolumn{7}{|l|}{ Objective oral health status } \\
\hline \multicolumn{7}{|l|}{ Changes in the oral mucosab } \\
\hline Yes & 80,0 & 20,0 & 1,00 & & & \\
\hline No & 78,1 & 21,9 & 1,11 & $0,51-2,43$ & 0,772 & 1,75 \\
\hline \multicolumn{7}{|c|}{ Use of removable dental prosthesis } \\
\hline No & 85,3 & 14,7 & 1,00 & & & \\
\hline Yes & 76,0 & 24,0 & 0,54 & $0,27-1,08$ & 0,075 & 1,23 \\
\hline \multicolumn{7}{|c|}{$\begin{array}{l}\text { Subjective oral health status - self-perception.... } \\
\ldots \text { of need for dental treatment } \mathrm{t}^{\mathrm{b}}\end{array}$} \\
\hline No & 75,7 & 24,3 & 1,00 & & & \\
\hline Yes & 78,7 & 21,3 & 0,84 & $0,54-1,32$ & 0,446 & 1,14 \\
\hline \multicolumn{7}{|c|}{$\begin{array}{l}\text {... toothache and painful gums in the previous } \\
\text { six months }{ }^{b}\end{array}$} \\
\hline Yes & 70,6 & 29,4 & 1,00 & & & \\
\hline No & 79,9 & 20,1 & 0,60 & $0,32-1,12$ & 0,099 & 1,86 \\
\hline \multicolumn{7}{|c|}{... uncomfortable feeling in the mouth, head } \\
\hline or neck & 79,3 & 20,7 & 1,00 & & & \\
\hline Yes & 77,2 & 22,8 & 1,13 & $0,62-2,04$ & 0,669 & 1,20 \\
\hline \multirow{2}{*}{\multicolumn{7}{|c|}{$\begin{array}{l}\text { No } \\
\text { impacts due to oral disorders }\end{array}$}} \\
\hline & & & & & & \\
\hline Yes & 81,9 & 18,1 & 1,00 & $0,67-2,83$ & 0,362 & 1,54 \\
\hline No & 76,7 & 23,3 & 1,38 & & & \\
\hline
\end{tabular}

${ }^{a}$ Estimated values corrected for design effect. ${ }^{b}$ Variation $\mathrm{n}=492$ due to loss of information. ${ }^{\mathrm{c}}$ Based on minimum salary in 2008 (R\$ 415).

and disease prevention within the SUS ${ }^{3}$. Although this finding is a cause for optimism, it should be highlighted that a considerable portion of elderly people in Brazil have never used dental services ${ }^{35}$. Furthermore, the prevalence rate for oral cancer self-examination among individuals that used the SUS is far from ideal $(100 \%$ of oral cancer self-examination among individuals that received dental care), suggesting that there is considerable room for improvement in current health promotion policies to address oral cancer self-examination, especially with regard to the elderly, given their greater susceptibility to oral cancer $^{26}$ and vulnerability attributed to level of health literacy ${ }^{29}$. Studies have shown that educational activities can lead to an increase in knowledge and wider adoption of self-care practices ${ }^{16}$. In any event, this finding legitimises oral health care policies that respond to the needs of the elderly created in $2004^{4}$ and corroborates the importance of the inclusion of an oral health team in the $\mathrm{ESF}^{13,36}$, which led to an increase in the provision 
Table 3. Multiple analysis of factors associated with oral self-examination among the elderly in Montes Claros/ Minas Gerais, 2008/2009.

\begin{tabular}{|c|c|c|c|}
\hline & OR & CI 95\% & $\mathbf{p}$ \\
\hline \multicolumn{4}{|l|}{ Personal characteristics } \\
\hline \multicolumn{4}{|l|}{ Income measured in number of minimum salaries ${ }^{a}$} \\
\hline One or less & 1,00 & & \\
\hline More than one & 1,80 & $1,06-3,05$ & 0,029 \\
\hline \multicolumn{4}{|l|}{ Schooling (years of study) } \\
\hline 0 to 4 years & 1,00 & & \\
\hline 5 years or over & 2,06 & $1,14-3,74$ & 0,018 \\
\hline \multicolumn{4}{|l|}{ Health services/health costs } \\
\hline \multicolumn{4}{|l|}{ Type of dental service used } \\
\hline \multicolumn{3}{|l|}{ Philanthropic } & 0,016 \\
\hline SUS & 2,77 & & \\
\hline \multicolumn{4}{|l|}{ Reason for using dental service ${ }^{b}$} \\
\hline Treatment & 1,00 & $0,25-0,91$ & 0,028 \\
\hline Routine & 0,48 & & \\
\hline \multicolumn{4}{|l|}{ Health behaviours } \\
\hline \multicolumn{4}{|l|}{ Current or previous drinking habit ${ }^{\mathrm{b}}$} \\
\hline Yes & 1,00 & $0,26-0,86$ & 0,016 \\
\hline No & 0,47 & & \\
\hline \multicolumn{4}{|l|}{ Health outcomes } \\
\hline \multicolumn{4}{|l|}{ Objective oral health status } \\
\hline \multicolumn{4}{|l|}{ Use of removable dental prosthesis } \\
\hline No & 1,00 & $1,03-5,46$ & 0,041 \\
\hline Yes & 2,37 & & \\
\hline \multicolumn{4}{|l|}{ Subjective oral health status } \\
\hline \multicolumn{4}{|l|}{ Impacts due to oral disorders ${ }^{\mathrm{b}}$} \\
\hline Yes & 1,00 & $1,14-4,59$ & 0,021 \\
\hline No & 2,28 & & \\
\hline
\end{tabular}

${ }^{a}$ Based on minimum salary in $2008(\mathrm{R} \$ 415) .{ }^{\mathrm{b}}$ Variation $\mathrm{n}=492$ due to loss of information.

of oral health care, including oral health promotion and disease prevention. Public oral health care services should extend beyond clinical care to include the community, epidemiological surveys, health promotion and disease prevention, and health education ${ }^{33}$. The findings of this study show that a number of advances gave been made in this respect.

Primary health care plays an essential role in raising awareness about good oral health among the elderly and promoting self-care and healthy attitudes ${ }^{37}$. The use of dental services with appropriate regularity contributes towards disease prevention in all agesand facilitates early diagnosis and treament ${ }^{37}$. However, oral cancer self-examination was less common among individuals who had had regular and periodic dental treatment, possibly because the "regular and periodic dental treatment" was a consequence of oral problems requiring curative care, such as toothache and dental extractions. It is important to highlight the need for regular and periodic dental care among older people, with a focus on health promotion, health education and disease prevention, and for the provision of information to promote appropriate oral health behaviours, particularly oral cancer self-examination. The majority of public health campaigns and activities which target the prevention of oral cancer emphasise the need for lifestyle changes, including stopping smoking and drinking ${ }^{14}$. Oral cancer self-examination can lead to the self-perception of the need for professional care. As such, there is a greater chance of an oral exam being carried out by a surgeon or dentist, if oral self-examination has already occurred. Therefore, if on the one hand it may seem counter-intuitive that the chance of self-examination is less among those who routinely 
use dental services, on the other hand, evidence shows that the perception of problems identified during self-examination result in the seeking of treatment, which is consistent with the findings of this study.

Oral cancer self-examination was less common in individuals with no current or previous drinking habit. Alcohol consumption is a risk factor for oral cancer ${ }^{910}$. A case study carried out in the United States with 1,114 cases and 1,268 controls observed that the risk of occurrence of mouth and throat cancer increases with increased alcohol consumption'. Awareness of the carcinogenic potential of alcohol may engender preventative behaviours, such as performing oral cancer self-examination and reducing alcohol intake, especially among individuals with a high level of health literacy ${ }^{17}$. The reduced likelihood of oral cancer self-examination among individuals with no current or previous drinking habit suggests that access to information may lead to a wider adoption of self-care behaviours. However, structural issues should be taken into account in order to guarantee greater access to information, regardless of the risk related to current or previous drinking habits.

Other etiological factors associated with oral cancer must also be addressed by health promotion/education activities, including the possibility of cancerous oral lesions attributed to ill-fitting removable dentures. The present study shows that the likelihood of oral cancer self-examination was greater among individuals who use removable dental prostheses. The use of ill-fitting removable dental prostheses can lead to an increase in the prevalence of mucosal lesions. A previous study found that the prevalence of mucosal lesions (inflammatory fibrous hyperplasia and candida), often caused by ill-fitting prostheses, was greater in individuals over 60 years of age in both sexes ${ }^{38}$. A case-control study undertaken in the Hospital das Clínicas at the University of São Paulo, showed that oral lesions caused by ill-fitting dentures were associated with oral canceramong smokers, and highlighted that the chronic irritation of the oral mucosa by dentures accentuated the carcinogenic potential of tabacco ${ }^{39}$. The use of dental prostheses may lead to a greater likelihood of self-examination due to the greater manipulation of the oral cavity by the user, or the possibility of an increased perception of oral problems related to soft tissue, the latter of which may hinder the use of the prosthesis. Furthermo- re, dentists may be more likely to give guidance on the importance of oral cancer self-examination to prosthesis users.

Oral cancer self-examination was more prevalent in individuals who did not experience discomfort attributed to oral condition, possibly because individuals with a perception of good oral health status really do have good oral health because they adopt preventative measures, including oral cancer self-examination. However, it is known that the self-perception of oral health status, one of the elements of quality of life ${ }^{40}$, is a subjective judgement made by the individual of his or her functional, social and psychological well-being ${ }^{41}$. A perception of good oral health statusin older people whose oral health status is actually poor may be attributed to the acceptance of ageing and its effects ${ }^{42}$.

This study has a number of limitations. The transversal nature of this investigation means that it was not possible to examine the temporal relationship between the associations observed by the study. Furthermore, certain variables included in the theoretical model adopted by this study were not examined. However, the study observed an association between self-examination and personal characteristics, health services/health costs, health behaviours, and subjective and objective oral health status, demonstrating the adequacy of the theoretical model adopted by the study.

\section{Conclusion}

Overall prevalence of oral cancer self-examination among the study sample was low. The highest prevalence rate was observed among elderly people who used dental services provided by the SUS. It is necessary to widen access to quality dental services and health promotion activities, including the propagation of information on how to prevent oral cancer and the importance of oral cancer self-examination, and guidance on how to perform self-examination, especially among the elderly. These actions should be widened to target the elderly as a whole, with emphasis on individuals who are treated outside the SUS, people who seek regular and periodic dental treatment, socially disadvantaged persons, people who do not have a drinking habit, people that do not use removable dental prostheses, and people who do not experience discomfort attributed to oral condition. 


\section{Collaborations}

AMEBL Martins, JGS Souza, DS Haikal, AMB

Paula, EF Ferreira and IA Pordeus participated equally in all stages of the preparation of this article. 


\section{References}

1. Paim J, Travassos C, Almeida C, Bahia L, Macinko J. The Brazilian health system: history, advances, and challenges. Lancet 2011; 377(9779):1778-1797.

2. Brasil. Ministério da Saúde (MS). Secretaria de Vigilância em Saúde. Departamento de Análise de Situação de Saúde. Saúde Brasil 2008: 20 anos de Sistema Único de Saúde (SUS) no Brasil. Brasília: MS; 2009.

3. Brasil. Ministério da Saúde (MS). Secretaria de Atenção a Saúde. Estatuto do Idoso. $3^{\circ}$ ed. Brasília: MS; 2013.

4. Brasil. Ministério da Saúde (MS). Secretaria de atenção a Saúde. Coordenação Nacional de Saúde Bucal. Diretrizes da Política Nacional de Saúde Bucal. Brasília: MS; 2004.

5. Christensen K, Doblhammer G, Rau R, Vaupel JW. Ageing populations: the challenges ahead. Lancet 2009; 374(9696):1196-1208.

6. Schmidt MI, Duncan BB, Silva GA, Menezes AM, Monteiro CA, Barreto SM, Chor D, Menezes PR. Doenças crônicas não transmissíveis no Brasil: carga e desafios atuais. Lancet 2011; 377:2042-2053.

7. Instituto Nacional do Câncer (Inca). Estimativa de incidência de câncer no Brasil para 2014. Rio de Janeiro: Inca; 2014. [acessado 2014 set 3]. Disponivel em http://www.inca.gov.br/estimativa/2014/sintese-de-resultados-comentarios.asp

8. Warnakulasuriya S. Global epidemiology of oral and oropharyngeal cancer. Oral Oncology 2009; 45(45):309-316

9. Blot WJ, McLaughlin JK, Winn DM, Austin DF, Greenberg RS, Preston-Martin S, Bernstein L, Schoenberg JB, Stemhagen A, Fraumeni Junior JF. Smoking and drinking in relation to oral and pharyngeal cancer. Cancer Res 1988; 48(11):3282-3287.

10. Petersen PE. Oral cancer prevention and control - The approach of the World Health Organization. Oral Oncology 2009; 45(4-5):454-460.

11. Conway DI, Petticrew M, Marlborough H, Berthiller J, Hashibe M, Macpherson LMD. Socioeconomic inequalities and oral cancer risk: A systematic review and meta-analysis of case-control studies. Int J Cancer 2008; 122(18):2811-2819.

12. Sankaranarayanan R, Ramadas K, Thomas G, Muwonge R, Thara S, Mathew B, Rajan B. Oral Cancer Screening Study Group. Effect of screening on oral cancer mortality in Kerala, India: a cluster-randomized controlled trial. Lancet 2005; 365(9475):1927-1933.

13. Antunes JLF, Toporcov TN, Wunsch-Filho V. Resolutividade da campanha de prevenção e diagnóstico precoce do câncer bucal em São Paulo, Brasil. Rev Panam Salud Publica 2007; 21(1):30-36.

14. Torres-Pereira CC, Angelim-Dias A, Melo NS, Lemos Júnior CA, Oliveira EMF. Abordagem do câncer da boca: uma estratégia para os níveis primário e secundário de atenção em saúde. Cad Saude Publica 2012; 28(Supl.):S30-39.

15. Torres-Pereira C. Oral cancer public policies: Is there any evidence of impact? Braz Oral Res 2010; 24(Spec Iss 1):37-42.

16. Elango KJ, Anandkrishnan N, Suresh A, Iyer SK, RamaIyer SK, Kuriakose MA. Mouth self-examination to improve oral cancer awareness and early detection in a high-risk population. Oral Oncology 2011; 47(7):620624.
17. Sørensen K, Van den Broucke S, Fullam J, Doyle G, Pelikan J, Slonska Z, Brand H. Health literacy and public health: a systematic review and integration of definitions and models. BMC Public Health 2012; 12:80.

18. Coulter A, Ellins J. Effectiveness of strategies for informing, educating, and involving patients. BMJ 2007; 335(7609):24-32

19. Martins AMEBL, Guimarães ALS, De'Paula AMB, Pires CPB, Haikal DAS, Silva JMS, Silveira MF, Caldeira TCR, Eleutério NB, Silveira AM, Almeida BM, Almeida CM, Freitas CV, Botelho DMM, Chaves KTS, Pereira PMB, Lima RS, Pereira SM, Silva TF, Duarte VM, Silva VEP, Pordeus IA. Levantamento epidemiológico das condições de saúde bucal da população de Montes Claros Projeto SBMOC. RUC 2012; 14(1):3-14.

20. Bertolucci PHF, Brucki SMD, Campacci SR, Juliano Y. O mini-exame do estado mental em uma população geral: impacto da escolaridade. Arq Neuropsiquiatr 1994; 52(1):1-7.

21. Kochhann R, Varela JS, Lisboa CSM, Chaves MLF. The Mini Mental State Examination: review of cutoff points adjusted for schooling in a large Southern Brazilian sample. Dement Neuropsychol 2010; 4(1):35-41.

22. World Health Organization (WHO). Oral health surveys: basic methods. $4^{\text {th }}$ ed. Geneva: WHO; 1997.

23. Oliveira BH, Nadanovsky P. Psychometric properties of the Brazilian version of the oral Health Impact Profile-Short form. Community Dent Oral Epidemiol 2005; 33(4):307-314.

24. Locker D, Quinõnez C. To what extent do oral disorders compromise the quality of life? Community Dent Oral Epidemiol 2011; 39(1):3-11.

25. Brasil. Ministério da Saúde (MS). Conselho Nacional de Saúde. Resolução no 196 de 10 de outubro de 1996. Diretrizes e Normas Regulamentadoras de Pesquisas Envolvendo Seres Humanos. Diário Oficial da União 1996; 16 out.

26. Shiboski CH, Shiboski SC, Silverman Junior S. Trends in oral cancer rates in the United States, 1973-1996. Community Dent Oral Epidemiol 2000; 28(4):249-256.

27. Souza LRB, Ferraz KD, Pereira NS, Martins MV. Conhecimento acerca do câncer bucal e atitudes frente à sua etiologia e prevenção em um grupo de horticultores de Teresina (PI). Rev Bras Cancerol 2012; 58(1):3139

28. Correa MC, Tarquinio SBC, Oliveira LJC, Peres MA, Peres KG, Gigante DP, Horta BL, Demarco FF. Factors associated with prevalence of oral lesions and oral self-examination in young adults from a birth cohort in Southern Brazil. Cad Saude Publica 2013; 29(1):155 164.

29. Torquato R, Massi G, Santana AP. Envelhecimento e Letramento: A Leitura e a Escrita na Perspectiva de Pessoas com Mais de 60 Anos de Idade. Psicol Reflex Crít 2011; 24(1)89-98.

30. Silva SRC, Fernandes RAC. Autopercepção das condições de saúde bucal por idosos. Rev Saude Publica 2001 35(4):349-355.

31. Martins AMEBL, Barreto SM, Silveira MF, Santa-Rosa TTA, Pereira RD. Autopercepção da saúde bucal entre idosos brasileiros. Rev Saude Publica 2010; 44(5):912922. 
32. Choi Y, Dodd V, Watson J, Tomar SL, Logan HL, Edwards H. Perspectives of African Americans and dentists concerning dentist-patient communication on oral cancer screening. Patient Educ Couns 2008; 71(1):41-51.

33. Antunes JLF, Narvai PC. Políticas de saúde bucal no Brasil e seu impacto sobre as desigualdades em saúde. Rev Saude Publica 2010; 44(2):360-365.

34. Rocha RACP, Goes PSA. Comparação do acesso aos serviços de saúde bucal em áreas cobertas e não cobertas pela Estratégia Saúde da Família em Campina Grande, Paraíba, Brasil. Cad Saude Publica 2008; 24(12):2871-8280.

35. Martins AMEBL, Barreto SM, Pordeus IA. Uso de serviços odontológicos entre idosos brasileiros. $\mathrm{Rev} \mathrm{Pa-}$ nam Salud Publica 2007; 22(5):308-316.

36. Brasil. Portaria $n^{\circ} .1 .444,28$ de dezembro de 2000. Estabelece incentivo financeiro para reorganização da saúde bucal prestada nos municípios por meio do Programa Saúde da Família. Diário Oficial da União 2000; 29 dez.

37. Newman JF, Gift HC. Regular pattern of preventive dental services - a measure of access. Soc Sci Med 1992; 35(38):997-1001.

38. Rocha ES; Mattar DDS; Martins CR. Lesões de mucosa bucal em idosos. Rev CROMG 2002; 8(2):134-143.

39. Vaccarezza GF, Antunes JLF, Michaluart-Júnior P. Recurrent sores by ill-fitting dentures and intra-oral squamous cell carcinoma in smokers. J Public Health Dent 2010; 70(1):52-57.

40. Martins AMEBL, Jones KM, Souza JGS, Pordeus IA. Associação entre impactos funcionais e psicossociais das desordens bucais e qualidade de vida entre idosos. Cien Saude Colet 2014; 14(8):3461-3478.

41. Locker D. Clinical correlates of change in self perceived oral health in older adults. Community Dent Oral Epidemiol 1997; 25(3):199-203.

42. Haikal DS, Paula AMB, Martins AMEBL, Moreira NA, Ferreira EF. Autopercepção da saúde bucal e impacto na qualidade de vida do idoso: uma abordagem quanti-qualitativa. Cien Saude Colet 2011; 16(7):3317-3329.

Article submitted 03/08/2014

Approved 11/10/2014

Final version submitted 11/13/2014 